\title{
Experiences from Assessing Safety in Vingis Park, Vilnius, Lithuania
}

\author{
Vania Ceccato $^{1} \&$ Magnus Hansson ${ }^{1}$ \\ ${ }^{1}$ School of Architecture and the Built Environment, Royal Institute of Technology (KTH), Stockholm, Sweden \\ Correspondence: Vania Ceccato, School of Architecture and the Built Environment, Royal Institute of \\ Technology (KTH), Drottning Kristinas väg 30, 10044 Stockholm, Sweden. Tel: 46-8-790-8625. E-mail: \\ vania.ceccato@abe.kth.se
}

Received: August 14, 2013 Accepted: September 13, 2013 Online Published: October 11, 2013

doi:10.5539/res.v5n5p1 URL: http://dx.doi.org/10.5539/res.v5n5p1

\begin{abstract}
The aim of this article is to suggest a multi-method approach for assessing safety in parks. The study is based on the analysis of police crime data combined with information from a safety walk and safety survey of park users. The framework is tested in an urban park, Vingis, in the inner city of Vilnius, the capital of Lithuania. Findings show that Vingis is perceived as a safe park, but, compared with police statistics, the survey and the safety walk provide a more nuanced diagnostic of safety in this green area. Vingis' safety is compromised by car traffic and illicit parking practices, the park's poor capacity to accommodate users' needs (e.g. the elderly, parents with small children, young people) and the inadequate infrastructure for users at certain times, such as in the evenings and dark months of the year. Patterns of safety expressed by citizens of Vingis park do not differ from the ones found in parks elsewhere (both in relation to their physical and social environment), despite the recent transformations Vilnius, as the capital city, has overcome since the country's independence. The article concludes with an assessment of the proposed framework and directions for research and intervention.
\end{abstract}

Keywords: green areas, crime, disorder, fear, safety audit, Vilnius, Lithuania

\section{Introduction}

Urban parks and open green spaces are of strategic importance for quality of life since they contribute to it in many ways (Chiesura, 2004; Hansmann et al., 2007; Thompson et al., 2012). Research indicates the importance of green areas and parks for our health and sense of well being; these qualities are often internalised as commodities, which explains why individuals pay more for a property which is located close to a natural amenity, such as a park (Peiser \& Schwann, 1993; Tyrvainen, 1997; Geoghegan, 2002; Nicholls \& Crompton, 2005). However, not all parks are synonyms of urban quality. Parks may also be associated with unsafe places, especially in inner city areas (Mollenkopf \& Flaschenträger, 2001). Parks have places that may put individuals at higher risk for victimisation and/or make them feel unsafe. Offenders can use parks to facilitate their activities, including target selection and examination and disposal of stolen goods (Michael et al., 2001). Darkness, pathways and borders in parks trigger fear, particularly among women and those who are more physically vulnerable, such the elderly and disabled (Herzog \& Kirk, 2005; Fobker \& Grotz, 2006).

The objective of this study is to make a contribution to this research area by proposing a multi-method approach for assessing safety in parks. The study tests such an approach using an urban park, Vingis; a green area in the inner city of Vilnius, the capital of Lithuania.

The selection of Vingis Park as a case study is based on the fact that little is known internationally about safety in the Baltic Countries (see, for instance, Dymen, 2009). Only a small number of studies have reported the nature of urban crime in socialist cities (for a review, see e.g., Ceccato \& Oberwittler; Ceccato, 2009). Another reason, as pointed out by Ceccato and Lukyte (2011), is that there is a need to assess safety in more detail in cities that have overcome a transition from a planned to a market economy with the end of the Soviet domination in early 1990s (for more details see Andrews, 2005; Tosics, 2005; Tsenkova, 2006). This is because, as suggested by Tosics (2005), socialist cities seem to be following a different development path from cities in Western Europe. Suburbanisation has been fed by influx of poorer population from less developed regions. Some of these are wealthy suburban compounds, defining clear patterns of geographical segregation and heightened fear (Hirt, 2012). In relation to other Eastern European cities, Vilnius has had one of the highest concentrations of poor people, exceeding $15 \%$ in 2000s (Tsenkova, 2006). 
Another issue of relevance in Eastern European cities is the changes and current distribution of intra-urban land use, including parks. Socialist cities, compared to Western cities, have had high shares of industrial land use in detriment of public services, including parks, and residential use (UNECE, 1997:18). Inner city areas have given place to commercial developments, shopping centres and new housing areas (Andrews, 2005; Hirt, 2012), that generate an entirely different set of routine activity in the areas. Urban parks, particularly in central areas (such as Vingis), have become a 'scarce amenity', a resource that attend those who reside in the area as well as Vilnius population in general. All these afore mentioned changes are believed to have affected both crime levels and overall perceived safety of public places, making therefore Vingis park an interesting case study.

This article is also a contribution to the growing literature on perceived safety in public places, responding to calls by Damyanovic (2007), Whitzman et al. (2009), Ceccato and Lukyte (2011), among others. This particular study has been made possible by georeferenced police crime data for Vingis and by a safety walk and safety survey performed by one of the authors.

The article has the following structure. Section 2 reviews the literature of benefits and disamenities of parks, followed by a discussion of patterns of perception of safety in urban environments. The final part of this section reviews in the literature three forms of safety measurement (crime maps, safety walks and safety surveys). Section 3 frames Vingis Park as the study area, section 4 describes the method and section 5 presents the results. The article ends with final considerations and recommendations for future research and intervention.

\section{Theoretical Background}

\subsection{The Nature of Parks}

Parks provide recreation opportunities and amenities, which have an intrinsic economic value. They provide important environmental benefits, such as air and water purification, wind and noise filtering, or microclimate stabilization, but also social and psychological benefits. Research on the use of urban parks and green areas confirms beliefs about their benefits of residents' stress-reduction and mental health (Jim and Chen, 2010). Although there is no single accepted definition of a park, Hilbon (2009:4) suggests that a park is "a bounded area of public open space that is maintained in a 'natural' or semi-natural (landscaped) state and set aside for a designated purpose, usually to do with recreation. Parks are often enclosed by a boundary barrier, which may be permeable or semi-permeable (a hedge, fence, or wall)".

Parks may also be associated with disamenities, such as crime and disorder. A risky park might be "a place where crime and disorder have become the norm to the degree that local users consider the park unsafe, try to avoid being in the park, and limit their time in the park to necessary activities. Crime and public disorder such as vandalism, littering, dog fouling, alcohol and drug abuse, and public sex have become the dominant activities in the park" (Hilborn, 2009:5-6). The author also exemplifies a safe park: "parents take children there, females go there as often as males, elderly people regularly visit the park and workers have lunch or take breaks there."

As suggested by Groff and McCord (2011), the numbers of facilities present within a park are important for understanding its crime rate. Groff and McCord's (2011) results show significantly lower crime rates in parks with tennis courts and other fields, as they attract more users who are organized or who have defined roles, for example coaches, referees and spectators. They found that public transit stops and streets around parks also have significantly lower disorder-related crime because more people around and in parks provide more surveillance. Their results show that parks surrounded by mixed land use areas have high crime rates. They also suggest that safety in parks does not relate to the risk of being a victim of crime per se, but to the effects of the presence of certain groups spending time in these public places. Knutsson (1997) suggested the term "illegitimate users" in parks to describe those who "disturb and threaten legitimate users of parks" and create "social and physical disorder". However, this notion of illegitimate users is, as we submit here, unfortunate, since it creates a barrier between park users, and undermines the fundamental idea of public places as a common good; a democratic right for all citizens. There is reason to agree with Hilborn (2009:13), who suggests that "a park will always be a contested space: a dog owner wants his dog to run freely, but a runner or a parent with small children wants the dog on a leash. Such conflicts are inherent to the park: dog owners versus runners, the old versus the young, drinkers versus non-drinkers". Challenges lie ahead in striving for accessible public places that accommodate differences but are welcoming for all. In the next section, we focus on the challenges of embracing individual's differences in perception of urban environments.

\subsection{Perception of Safety in Urban Environments}

Factors contributing to fear at the parks are related to both the physical landscape and the social activities that take place in these settings. Brennan and Zelinka (2011) stated that the way the physical environment is designed, 
built, and maintained affects the way people behave and feel. They suggest that physical features such as dark tunnels, dim lights, over grown bushes, are often associated to feelings of unsafety. As Whitzman (2007) suggests, different spaces can be understood differently: public spaces can be for example be liberating for some, frightening and dangerous for others. Some of these ideas date back to the 1960s and the 1970s when, for instance, Jacobs (1961) in her seminal work highlighted that the design of environment and mix of functions have a role to play in defining opportunities for social control, which can be crucial for crime and perceived safety of that particular place. Later, Newman (1972) defined the 'capacity of physical design to provide surveillance opportunities for residents and their agents' as natural surveillance (Newman, 1972:78). This should also be applied to public places, such as parks.

Parks are especial environments since they constitute an important component of the quality of life of citizens. Kuo and Sullivan (2001) shows that residents living in "green surroundings" report lower level of fear, fewer incivilities, and less aggressive and violent behaviour. However, the context in which a park is located may have an influence on levels of perceived safety. Research has shown that perceived safety in parks does not relate to the risk of being a victim of crime per se, but to the effects of the presence of certain groups spending time in these public places (Knutsson 1997; Groff \& McCord, 2011), in other words, fear of others (Sandercok, 2005) .

The perception of safety is also dependent on individual's characteristics, such as physical abilities, age, gender, socio-economic status, ethnic background, and previous personal experience. Personal experiences in parks can according to Tyrväinen and Mäkinen (2004) be based on aesthetic, visual, social and cultural characteristics, values and meanings. Valentine (1990) suggests that, in the absence of prior experience or familiarity with a particular place, judgment is likely to be based on preconceived ideas about similar settings and their occupants. For this reason, subjective information, for instance, how citizens perceive green areas, is needed in various planning and decision-making processes.

The feeling of unsafety typically increase with age, partially because of the inevitable increase in individuals' physical vulnerability. Previous research has shown that while young people are statistically more at risk of being victimized, older people tend to be more fearful. Research also shows a strong association between neighbourhood safety and physical inactivity among older adults (CDC 1999 quoted in Loukaitou-Sideris 2012).

Among the individual factors affecting the perception of safety, gender is perhaps the most important. First, women and men use space differently. Given today's gender roles, women still have greater responsibility for childcare, care of the elderly and household chores - activities often limited to the private sphere or places close to home (Larsson \& Jalakas, 2008). Women are more likely to have multiple purposes and multiple destinations within one trip than men (Kunieda \& Gauthier, 2007:6). Second, women and men are victimised by crime in different places. Overall, city centres, places with areas of mixed land use and transport nodes are often more criminogenic places than are residential areas (Sherman et al., 1989; Loukaitou-Sideris et al., 2002, 2009; Ceccato, 2009). However, regardless of which part of the city the women live in, the home tends to be more dangerous than any outdoor environment. The international literature on sexual violence indicates that rape, for instance, tends to occur in areas characterised by construction sites, parks, urban renewal, and temporary lodgings (e.g. Pyle, 1974; Canter \& Larkin, 1993), which also feeds the idea of parks as dangerous places, perhaps also perceived as more fearful for women than the rest of the city. Finally, women are more fearful than men, particularly in public spaces. Regardless of age, socio-economic status, ethnic-cultural or educational background or disability, research indicates that women often report higher levels of fear and anxiety than men (Pain, 1991; Box \& Hale, 1988; Koskela, 1999; Loukaitou-Sideris et al., 2009). Although most rapes are committed by someone the women know, still the idea of the rapist as "man jumping out of the bush" is prevalent and perceived as a more likely threat. In addition male victims of rape are underrepresented in crime statistics as many men do not report abuse to the police (which is also the case for many women). Fear of stranger-danger encountered in public spaces has been engrained in women from their childhood much more than in men. Among young people, Bromley and Stacey (2012) show that boys and girls have similar perspectives on the safety of their home areas, but significant gender differences exist for the city centre.

\subsection{The Measurement of Safety Using Crime Records, Safety Walks and Surveys}

If one takes 'safety' as a synonym of 'no crime' in an area, police statistics can be useful. Having detailed geographical knowledge of a city's criminogenic conditions provides a guide for targeting crime. The advantage is that this type of analysis indicates where crime takes place (alternatively, crime rates) by crime type, which makes it easy to establish a link between crime and its underlying factors in urban space. Police statistics also allow analysis of the time-space dimension of crime, which can serve as a background for safety improvements.

Police statistics are, however, not problem-free. They are technically available to researchers in most Western 
European cities, but data secrecy laws may restrict their use for professionals outside police organisations. Police records may vary in quality and their reliability depends on high reporting rates and police practices (for instance, problems arise where trust in public authorities is low) and on good georeferencing of addresses that is a cartographical step in the process (e.g. incomplete addresses create inaccuracies and, in certain cases, false hot spots of crime). Moreover, police statistics are often limited to crime location, which is incomplete information and should be combined, as often as possible, with data on offenders and victims. Police statistics are often used to provide a picture of high concentrations of crimes and, data allowing, measures of risk that can be split into, e.g., gender and age as categorical homogenous groupings. Moreover, police statistics alone cannot be used as a reference to explain fear of crime (see, e.g., Ceccato \& Snickars, 2000; Ceccato \& Lukyte, 2011), especially because for women crime, especially sexual violence, is seriously underreported and under-recorded.

Safety walks and safety surveys can be used as alternative sources of information about safety in parks. They have been used to demonstrate how daily fears translate into concerns about the physical environment, which is very useful information for planners. A safety walk (or audit) is an inventory of the features of an area (or a park) that affect individuals' perceptions of safety. Safety walks help individuals to look at a space that feels unsafe and determine why it feels unsafe. Safety walks were developed in late 1980s by Toronto's Metro Action Committee on Public Violence Against Women and Children as "a process which brings individuals together to walk through a physical environment, evaluate how safe it feels to them, identify ways to make the space safer and organize to bring about these changes" (WACAV Women's Action Centre Against Violence, Ottawa-Carleton, 1995:1). If individuals are concerned about their safety, it is seldom that they know where they can turn their comments other than the police, who are more interested in crime control than fear of crime. In reality, it is not only residents or those who work in the area that should act. Many different local authorities, at different levels, have to feel responsible for the safety of the outdoor environment to be tackled, for instance, a park. It may be property owners, city councils, public transport authorities, local housing and leisure associations, police and individual citizens themselves. Since they were developed, the concept of safety walks has been disseminated and adapted to different regions of the world. Whitzman et al. (2009) performed the most comprehensive study focusing on the effectiveness of safety audits. They show that, as any other tool, safety walks are not problem-free. Some of the highlighted challenges are difficulties in the implementation of recommendations and difficulties in involving the most vulnerable groups of women. Another concern is the fact that safety walks may create unreal expectations, as "safety is ensured by fixing up built-environment problems, and may divert resources from other, perhaps more substantive and complex, causes of crime and violence" (Whitzman, et al., 2009:207). However, the analysis shows evidence that safety walks are a valuable tool since they can be used by a wide variety of groups and in different circumstances and offer a wide range of benefits to participants from different backgrounds (Whitzman, et al., 2009:215).

Traditional surveys can be used when the objective is to obtain more than a general understanding of the knowledge and viewpoints that individuals have about a place. Structured and semi-structured interviews aim at specifically attending the needs of a certain target group or a particular part of the physical environment, such as park (Hilborn, 2009; Boverket et al., 2010). According to Dymen and Ceccato (2012), these methods attempt to identify an individual's vulnerability in certain urban environments and to take action to correct these features while simultaneously contributing to the individual's empowerment; a feeling that one has the power and opportunity to influence one's urban environments.

Taken together, these three sets of approaches can be used as complementary tools when the goal is to understand safety. In this study, they are applied to parks as suggested below:

(1) Vingis park, as any inner city public space, concentrates a number of criminal activities, such as vandalism, public disorder and violence. This may explain why women tend to feel more fearful than men in the park.

(2) The geography of crime data from the police can be helpful to identify specific places in parks that are more exposed to crime, which may trigger fear (although previous literature show a mismatch between crime geography and perception of safety in Vilnius, see e.g. Ceccato and Lukyte, 2011)

(3) Safety walk and safety surveys, can improve the understanding of problems of safety in parks and be a mechanism to empower citizens through participatory planning initiatives.

\section{The Study Area}

Vingis is the largest city park in Vilnius (162 hectares) located on Neris River. The park's history dates back several centuries and has witnessed major rallies and demonstrations over the course of Lithuanian history. Nowadays, the park is a popular venue for concerts (with internationally known artists) and sports competitions 
(e.g. marathons). Residents can also make use of carousels, bike lanes, an area for roller-skating and a playground. In the centre of the park, there is amphitheatre, Estrada, a café and a restaurant. Despite not being well known by residents, the park has also a botanic garden that is part of Vilnius University. In Vingis' eastern section, there is a memorial cemetery for soldiers who died during the First and Second World War. Except for the cemetery and the botanic garden, Vingis Park is managed and financed by Vilnius municipality. Many paths, both illuminated and non-illuminated, stretch across and around the park. Along the park's eastern and southern sections stretches the main road towards Kaunas (Lithuania's second largest town).

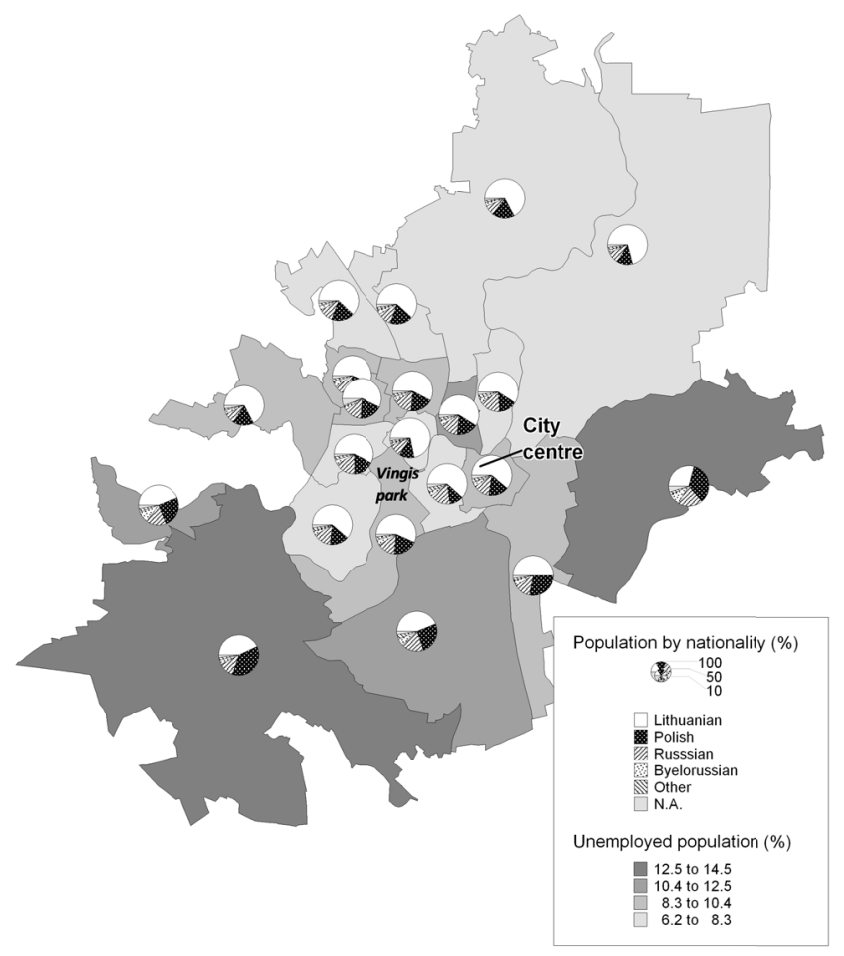

Figure 1. Vingis park and its socio-economic context in Vilnius

Population by nationality (\%) and Unemployed (\%, from 15 to 65 of age), Vilnius 2001. Data source: Statistics Lithuania, 2003

The residential area of Žverynas is located north and northeast of the park. Žverynas mainly consists of areas with higher- and middle-income homes. To the east and southeast, with the motorway in between, lies the town of Naujamiestis (new town). Naujamiestis consists both of homes and of areas of apartment blocks built from 1920s until the present day. Vilnius University and student accommodations are also located near the park.

Safety in Vingis Park is part of the municipal effort to make the city safe. According to Ceccato and Lukyte (2011), community crime prevention has become part of residents' daily practices in Vilnius since the mid-1990s. Since 2007, crime prevention in Vilnius has aimed at stimulating more public participation and collaboration of community members with police officers and neighbourhood administrators in crime prevention initiatives, with the ultimate goal of passing on the programme for developing a safe environment to active members of the community (Vilnius City Police Headquarters, 2007). The safety walk performed in this study was supported by Vilnius County Police Headquarters, Vilnius Municipality and the Centre for the Advancement of Gender Equality.

\section{Method}

Three approaches for assessing safety are discussed in this section; they are regarded as complementary (rather than competing) sources of information to provide a picture of safety in urban parks. The first method (crime mapping) aims to provide a comprehensive picture of the crime geography of the park in relation to neighbouring parts of the city. A safety walk is the second method explored in the study, providing a more dynamic, on-hand assessment of the park. The third method is based on a face-to-face interview with users of the park about their patterns of movement and perception of safety; focus is given to women at various ages. 
Crime records (a total of 25,347 from June 2004 to May 2005) come from Vilnius chief police headquarters. To make the data mappable, addresses were geocoded using Geographic Information Systems (GIS). Addresses had to be improved and geocoded and the data quality had to be tested (the final matching geocoding rate was around $95 \%$, but it varied by crime type).

Twenty-five individuals participated in the safety walk, which took about one and a half hours on a weekday in the spring of 2011. They were of varied ages, including children, invited through ads in the municipality. Thus, all participants were voluntary samples. The protocol (Figure 2) allowed for the participant to indicate where in the park problems occur, descriptions of the problems and some basic participant information, such as age and gender. Although the safety walk focused on the identification of unsafe places, participants were invited to indicate safe and pleasant places as well.

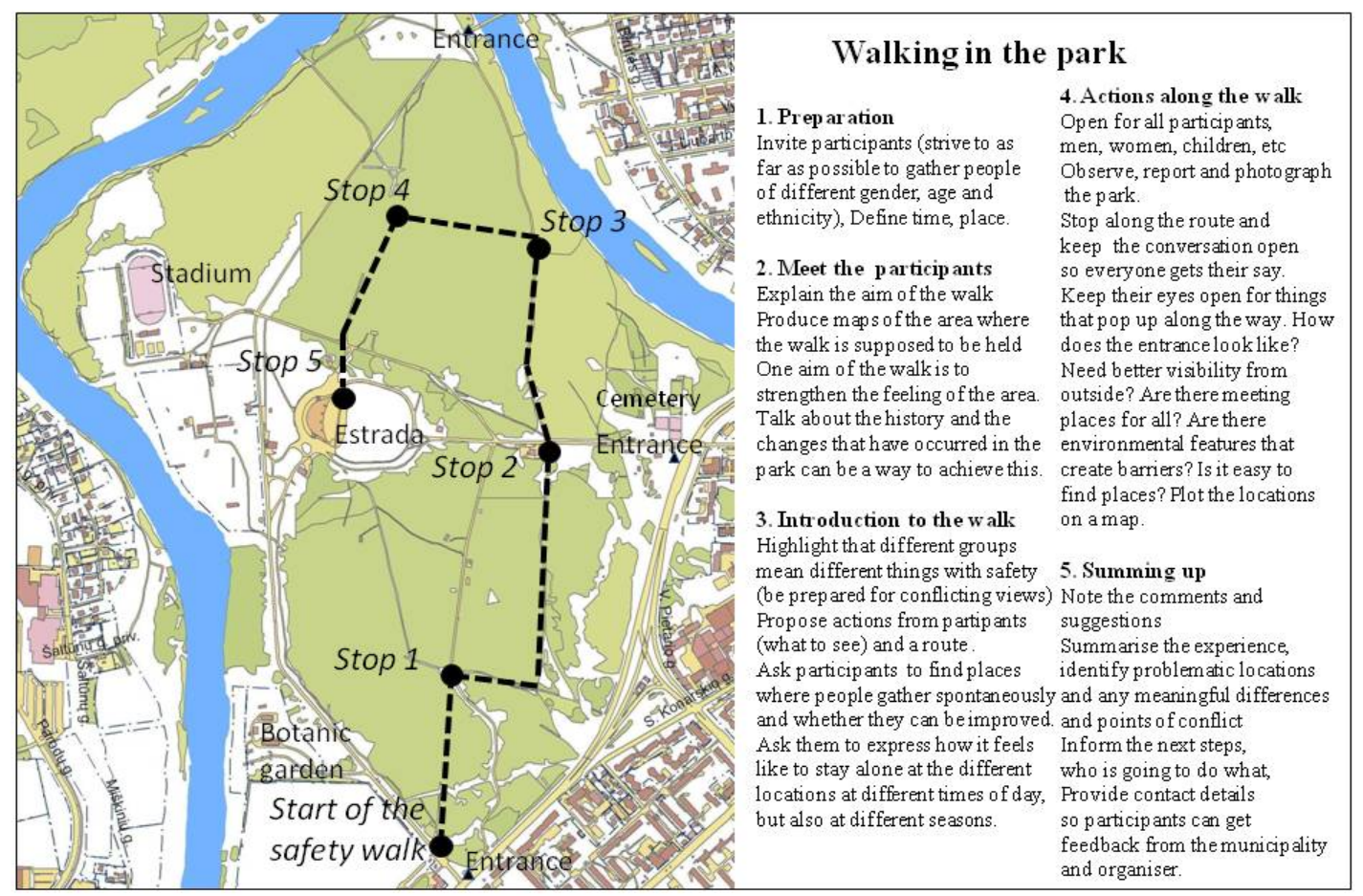

(a)

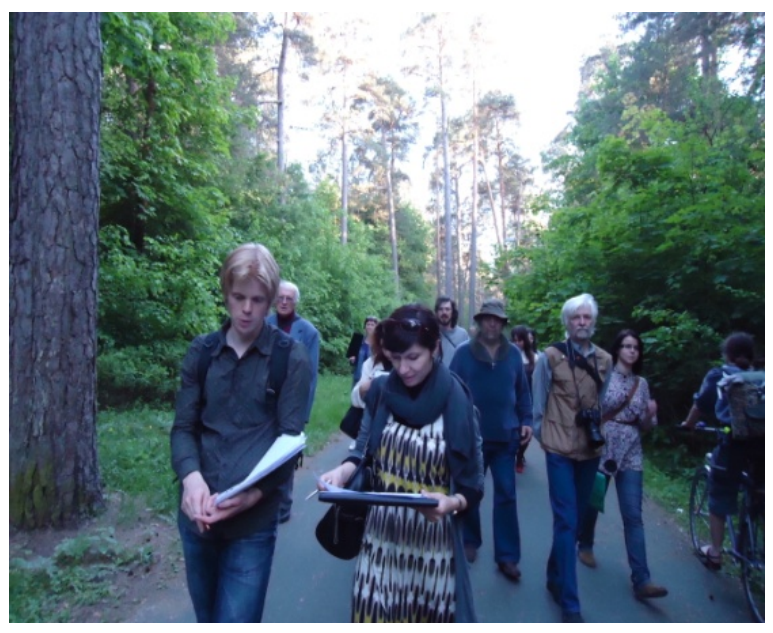

(b)

Figure 2. (a) The protocol and the route taken by participants of Vingis safety walk

(b) Participants (including children) in the safety walk 
The walk started with a presentation of the study's goals, which were to provide an arena for citizens to express their perceptions of safety in Vingis Park. The organiser informed the team of their role in the safety walk, i.e., to illustrate their perceptions of different places in the park, from safe to unsafe ones. In the suggested route, a selection of points prioritized minor roads crossing the park instead of large motorways, which are large and do not have much around (Figure 2). The safety walk brought out a range of issues often found in previous women's safety audits: broken lights, places where it is difficult to orientate (lack of signs), bushes growing in places which would make individuals feel unsafe, graffiti, trash, dogs running around freely in the park, very slippery pavements during the winter, prohibited parking areas, bikers riding on walking paths. During the walk, participants decided when and where to stop if they felt they had something to tell. A short discussion refined the comments, for instance, whether he or she always feels unsafe at that spot or only during the winter. Others were free to make reference to events that they were aware of and that happened in the park or at a particular spot in the park.

The survey was applied to a varied group of people (44 people in total), and of course not representative for the Vilnius population. They live in different parts of the city and happened to be at the park during the time the survey was performed. The interviewed group are park users and workers who did not have any relationship with those participating in the safety walk. Here this population is used just as an example of the method (but in future studies, data permitting, the method can be used to draw statically significant conclusions). They included parents with small children, youngsters, adults, elderly people and park workers ( 27 females and 17 males; most of the respondents were under 40 years old). The workers come to the park everyday and, thus, may have a different impression of the park than the visitors who come to the park for recreational purposes, meeting family and friends and/or engaging in sports. The interviewees are frequent users, they visit the park often during the spring-summer; one-fourth come to Vingis Park at least three times a week. The safety survey intended to provide more structured information about the process of identifying places perceived as unsafe, but also information of how users access the park in relation to where they live. The survey questions are available in Appendix.

\section{Results}

\subsection{The Geography of Crime}

Inner-city areas in Vilnius not only have a high concentration of crime but also other social problems related to alcoholics, drug addicts, and homeless people (Juskevicius, 2006: 76-77). According to Ceccato and Lukyte (2011) thefts and robberies are associated with mixed land use, following some of the main roads in the inner city areas, while violence shows a more dispersed pattern. In Vingis, mostly minor crimes occur, such as theft, pick pocketing and vandalism. In May 2011, one woman was raped and murdered in the forest in Vingis Park. Figure 3 shows that Vingis Park has few reported crimes and is located outside the main hot spots for thefts in Vilnius city centre (blue ellipses).

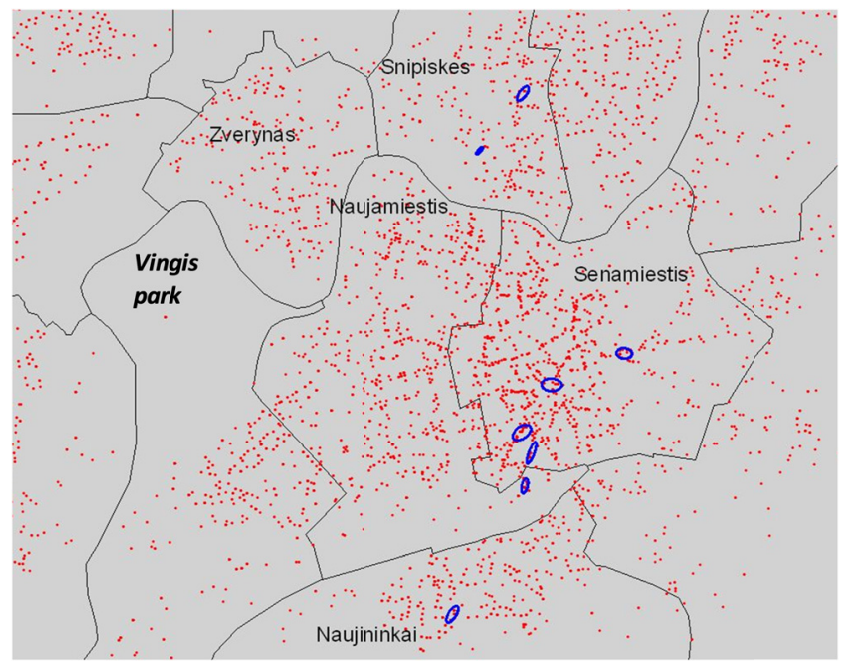

Figure 3. Vingis park is far way from Vilnius' theft clusters (blue ellipses), 2004-2005

Nearest Neighbour Hierarchical Cluster. Criteria for Small ellipses: Fixed distance: 100 meters, Minimum number of points per cluster: 50 . 
There are many possible reasons as to why Vingis Park is a low-crime area. First, Vingis Park is not a park that people cross to go to other places in the city centre; it is central but the park is encapsulated in the inner city area. Second, recreational amenities in the park (recreation centres, playground, stadium, and amphitheatre) attract a number of users during specific times who may act as capable guardians. Important to note that the park has some remote areas where people rarely visit them, and as crime depends on the convergence of motivated offenders and potential victims, these areas are relatively safe (although may not be perceived as so). Third, the park has very limited borders with the river on several sides, roads at the periphery of the park and fencing, which work as natural barriers from the rest of the city. This is a quality different from most parks where the boundaries are ill-defined. Fourth, the residential areas around the park do not stand out as high crime areas. The police data on offences do not show any information about the personal characteristics of the victims, which makes this type of data limited when investigating victimisation at parks. Another potential problem with official police statistics is that parks are often defined by only one pair of coordinates for the entire area, which results in external dumping of crime sites on the outskirts of the park or in the centre of the park, as may be the case here. For this particular study, crime maps were not very informative in showing where crime happens in Vingis Park. This does not mean that in other cities the police data will not be important, quite the opposite, data permitting police data can support the identification of 'problem areas' at parks (see e.g., Knutsson, 1997; Groff and McCord; 2011).

\subsection{Safety Walk}

The safety walk team in Vingis Park was composed of an organiser, citizens and representatives of Vilnius County Police Headquarters, Vilnius Municipality and the Centre for the Advancement of Gender Equality. The participants in the safety walk regarded safety (or lack of it) in Vingis Park as a multi-dimensional concept. Fast driving on main roads and illicit parking affect the overall feeling of safety according to the participants. They also indicated incivilities (e.g. littering, dog faeces, loud noises, shouting, public drinking), poor potential for surveillance (e.g. poor illumination in certain areas and/or blocked by trees, low flows of passers-by) and lack of basic park infrastructure (e.g., poor signs that affect the orientation of sporadic park users, lack of toilets, lack of social activities for children and youths, need for bicycle lanes, separation of pedestrians/bikers).

Participants believe that the southern section of the park needs to be better managed since most of problems are concentrated in that area. Necessary changes include not only specific adjustments to the park environment, but also additional services in certain places and transformations in the way that people feel about and use specific areas of the park. Some places were regarded as unsafe for children and/or adults in the dark months of the year. However, participants declare that they generally feel safe in the park, and perceive a low risk for violent or property crimes.

Although in the literature women tend to be more concerned than men with traffic safety (DeJoy, 1992), in our sample both men and women show similar concerns about cars in high speed across the parks. Both groups tend to be more concerned with traffic than violent crimes. An explanation for this is that those who participated in the safety walk are comfortable using the park and may not be intimidated by environments that would otherwise be frightened to other temporary visitors.

Comments and suggestions were summarized at the end of the walk, identifying problematic locations and any points of conflict in opinions. The group was informed of the next steps and provided with contact information so that participants could get feedback from the organiser of the safety walk. A summary of the evaluation of the protocols from the Vingis Park safety walk was later sent to the participants, to the mayor, the local police and made public in a newspaper article (Lithuania's biggest morning newspaper).

\subsection{Safety Survey}

Vingis Park is perceived as a safe place and is a point of interest of Vilnius. Users of the park feel that Vingis is safer than their own neighbourhood or safer than Vilnius city in general (Figure 4). This is particularly true for women: while they feel less safe in their own neighbourhood (16 percent) or in the city (12 percent), only 4 percent declared the park being unsafe. However, women are more often 'uncertain' about their own safety in Vingis Park than men are. Although men stated that they feel disturbed by annoying events that they witness in the park (e.g., drug addicts, drunk people, 'noisy teenagers', illegal parking, trash or bad management of the park), more than half of interviewed men declared feeling completely safe (versus less than one-third of women) (Figure 4a). One possible reason for women's fear is that parks trigger the fear of sexual violence (rape), which is often connected to a fear of dark places and of strangers. 


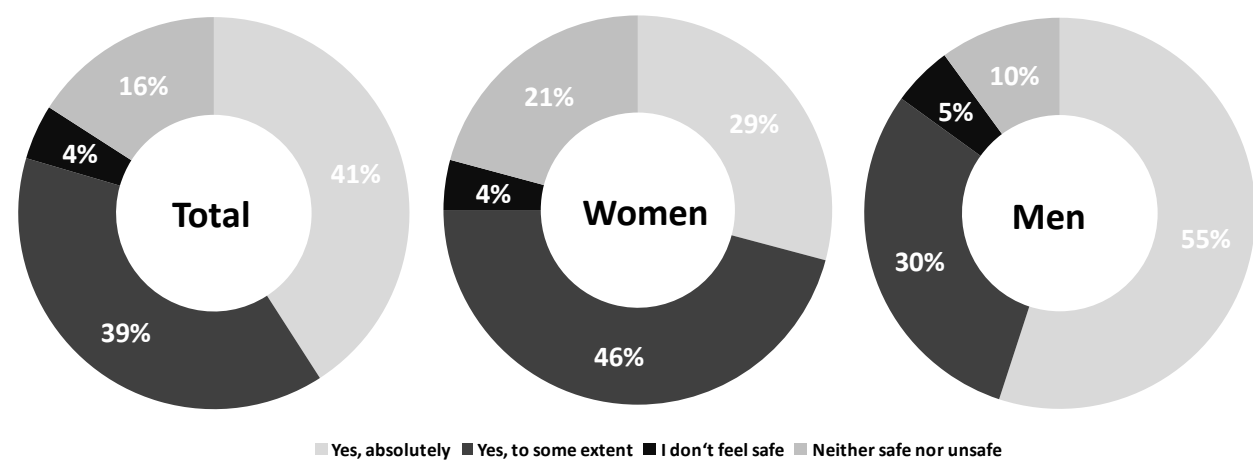

(a) I feel safe walking in Vingis park
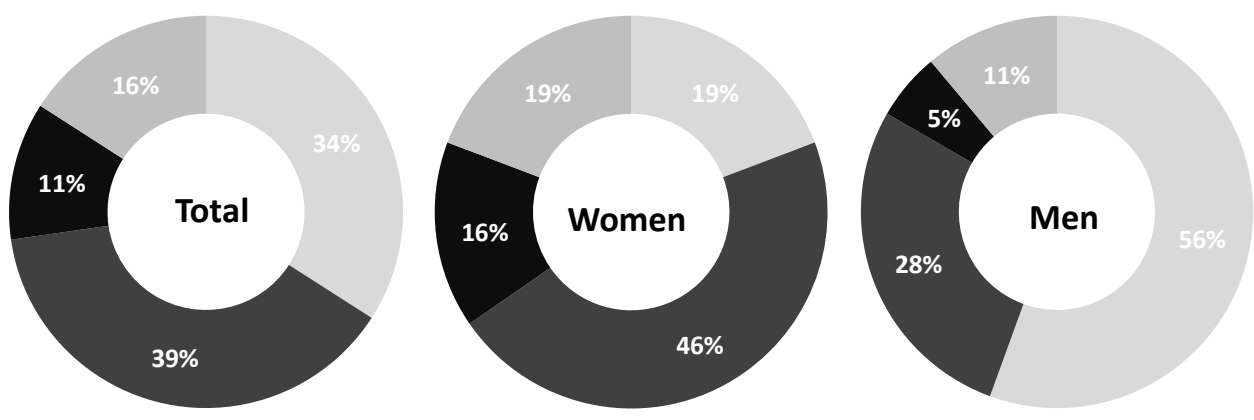

Yes, absolutely $\square$ Yes, to some extent $\square$ I don't feel safe $\quad$ Neither safe nor unsafe

(b) I feel safe in my neighbourhood
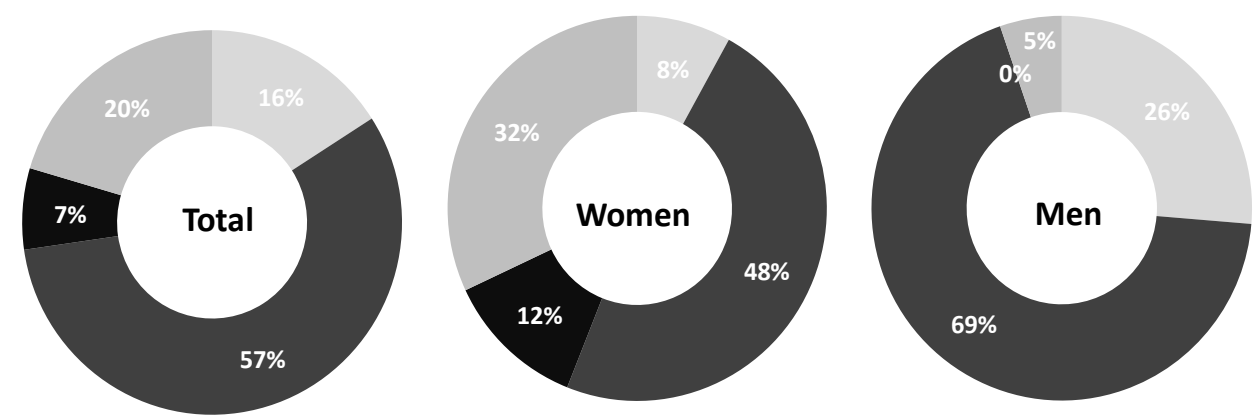

(c) I feel safe in Vilnius

Figure 4. Gender differences in perception of safety, users of Vilnius park, $N=44$

Vingis Park is used for recreation in the summer, e.g., meeting friends, engaging in sports, walking the dog. The reasons why people go to the park may differ. Parents with children, for example, come to the park because:

...it is a good place to visit since it is a calm, green area in the city centre. There is also a café, restaurant, children's playground, no traffic or houses. (parent with children)

However, not all parents agree:

On some paths lights are broken or missing, as well as toilets and a café (the café is closed on

Sunday and Monday). There is not enough infrastructure for feeding small children in the park. (woman with children)

The park is relatively large and, despite being central, very few people 'walk through' it. However, the car traffic on the main roads that cross the park is of concern:

I have been coming to the park for 30 years. The problem is the transport in the park, that cars are driving too fast ... cars are driving where people are working out and jogging. That is why I don't feel safe. I am also concerned for the kids I am coaching. A park is not a place for cars. 
(adult man)

As Hilborn (2009:13) suggests, "a park will always be a contested space". In Vingis Park, it is questionable who the "illegitimate" users are and how they contribute to the declared points of unsafety. On one hand, older citizens often bring their dogs for a walk despite the fact that animals are not allowed in the park, which is clearly posted. On the other hand, some users suggest that the park is a good place to meet friends and have a drink, perhaps one of the few free-zones from the eyes of their parents. There are also addicts who often spend long periods of time and/or reside in parks in the summer. Vingis Park is more often a meeting place in the hot months of the year, mostly during the day. The exception is for those who are working out in the evening (e.g., jogging or playing Frisbee, mainly around the stadium) or teenagers hanging out. The park is quite empty when it is dark, except for the main roads crossing the park. Women avoid going to the park after dark or during the dark months of the year, but not adult men. Some users are concerned with the people they meet in the park. Others are concerned with the low flows of people and that the police are only around for big events, which lead, they suggest, to poor social control (formal and informal).

There are drunk people; I don't like to see them. (young girl)

I feel safe when there are people around. I see police only during events. The main road and main path are safe. I do not go anywhere else. (adult woman)

As an exploratory exercise, respondents were invited to indicate which areas they perceived as unsafe. The answers were marked freehand on a map of the Park and were later transferred to a digital map (Figure 5). Most of the areas identified as unsafe are of two types: isolated, secluded, difficult-to-access places (e.g. pedestrian paths in the middle of the forest) or are near or along some of the main roads crossing the park or on the park's border. Safety was linked to both risk of crime and risk of traffic accidents.

The desire to walk in the park can depend on how nice the environment is perceived to be (e.g., Brennan and Zelinka 2011). It is possible that areas with traffic and, consequently, disturbing traffic noise do not stimulate people to stay or to even spend time in the park. The amphitheatre is by far regarded as the safest place in the park followed by other meeting places (e.g., stadium), street corners and entrances - all places that tend to concentrate people, and therefore, have a higher chance for social control and guardianship.

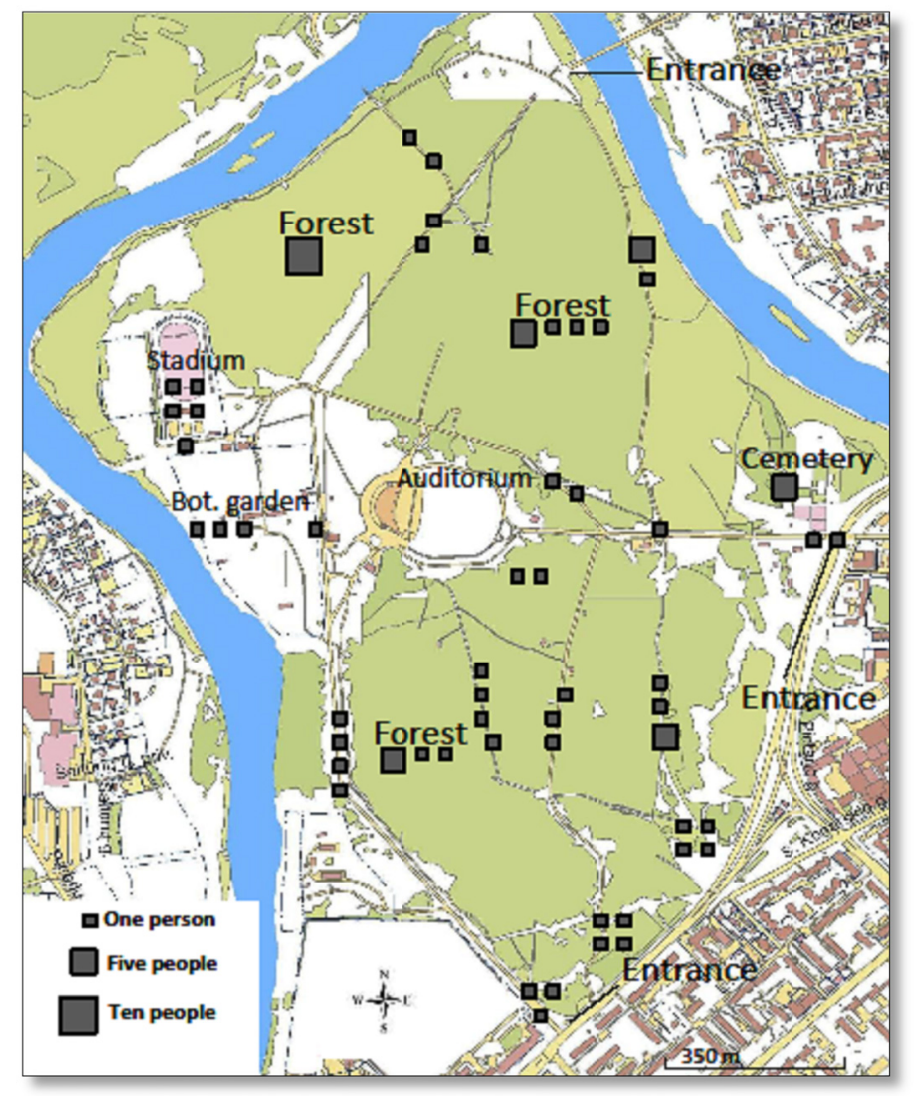

Figure 5. Unsafe places at Vingis park, Vilnius, according to users, $N=44$ 
Contrary to the safety walk, some differences in the patterns of perceived safety were found among the participants of the safety survey, but they are not major. Views on women's expected needs and behaviour in Vingis Park, as expressed by the participants, illustrate how easily gender stereotypes can be consolidated by the image of women as a fearful, dependent on other people's presence and passive being in the park. Parents with prams are reminded of 'their place' when other users make them feel restricted in the way they move around in the park. Comments and behaviours of this kind reinforce the idea of the park as a fearful arena that does not belong to woman's expected use of public sphere, and provides a tangible basis for women's fear (the fear of being attacked):

Sometimes we meet aggressive people who push the pram with the child inside to mark that there is not enough space for them to pass by. This is very scary for a parent with a child.

Similar views are expressed towards young people and their expected behaviour in public places. Youngsters may also be reminded about certain untold rules of park conduct, when they drink or when young girls spend time with their (boy) friends:

Sometimes young people are too free in their behaviour... Young people's behaviour is too intimate in public. (parent with children)

The case above shows that there were issues related to the use of park by young people. There is no question that the park should be welcoming for both young boys and girls, but there seems to be a need for a wide discussion on how young people can put their mark on a place without making other groups feel annoyed.

\section{Conclusions and Recommendations}

This study assessed the potential of combining police crime data with information from safety walks and a safety survey as a framework for safety evaluation in parks. Vingis Park, an inner city park in Vilnius, the capital of Lithuania, was used as case study.

Vingis Park is considered a safe park, but all agree that its safety is compromised by car traffic, the park's poor capacity to accommodate users' needs and its inadequate infrastructure for users in the evenings and dark months of the year. The sample used for this analysis is not representative for Vilnius citizens or park users, so any conclusion drawn here has to be taken cautiously. Findings also show that women more often declare feeling less safe in the park than men, but, surprisingly, safer in the park than in their own neighbourhood or in Vilnius overall. These findings corroborate previous findings. Ceccato and Lukyte (2011) show that despite the fact that 67 per cent of residents declare to feel unsafe in Vilnius, intra-urban data show that this fear is not equally distributed in space. Surprisingly, Vilnius' city centre, where Vingis is located, is perceived as a relatively safe place.

Table 1 summarises the strengths and challenges of the suggested approach. Crime records on a map can indicate where crime occurs, which can easily be associated with land use, demographic and socio-economic data and be a basis for intervention. Crime data is low cost (compared with safety surveys and audits) since it is often accessible from police statistics. However, one of the limitations using data on offences is that reflects people's willingness to report crime and often lacks information on the victims or offenders, making any analysis by group a difficult task. Another problem is that a park, like Vingis Park, often lacks coordinates for the entire area (or at least, parts of it), which underestimates the number of events that occur there.

The geography of crime on the map was not able to show the places where crime happened in Vingis Park, either because of poor geocoding practices and/or low reporting rates at the park. Although crime mapping did not allow an adequate comparison between crime geography and patterns of perceived safety for Vilnius, previous research has shown evidence that police records can become a good source of planning support in the future if crime data used to identify particular high crime areas (see, for instance, Groff \& McCord, 2011).

Another problem was that the safety walk was conducted during the day, in the spring and, remarkably, in a large group. Under these conditions, participants were asked not only to consider indicators of fear/safety but, as well, to 'imagine' them at different times of the day and year. The artificiality and limited scope of the situation (day, spring, group) and expectations of extrapolation to different circumstances and seasons seems to open itself up to a biased sampling. Some would suggest that it would be rather difficult to draw an 'accurate' landscape of fear and safety under these conditions.

Vilnius, as many other Eastern European cities, has undergone rapid changes since the countries' independence, which are believed to affect both crime levels and overall perceived safety. Data permitting, future studies should assess whether these recent transformations in the urban structure have had any impact on the way individuals perceive urban spaces, particularly public spaces, such as Vingis park. 
Table 1. Advantages and challenges of the multi-method framework

\begin{tabular}{lll}
\hline & Advantages & Challenges \\
\hline $\begin{array}{l}\text { Mapping the } \\
\text { geography of crime }\end{array}$ & $\begin{array}{l}\text { Shows exactly where crime occurs in } \\
\text { parks. }\end{array}$ & $\begin{array}{l}\text { A park often lacks coordinates for the entire } \\
\text { area, resulting in 'empty maps', as in Vingis }\end{array}$ \\
& $\begin{array}{l}\text { Can easily be associated with land use, } \\
\text { demographic and socio-economic data. }\end{array}$ & $\begin{array}{l}\text { sites on the outskirts of the park. } \\
\text { Low cost, data often accessible from } \\
\text { the police statistics. }\end{array}$ \\
& $\begin{array}{l}\text { Data often lacks information on the victims } \\
\text { or offenders. } \\
\text { Reflects people's willingness to report crime }\end{array}$
\end{tabular}

Safety walk

Safety survey
Allows classification of safe/unsafe places in the park by the user's socio-demographic characteristics, such as gender.

Allows a holistic approach to safety (e.g. traffic safety).

Encourages communicative planning, engaging both citizens and experts.

Empowers groups to change public spaces, such as parks.
Easy to show tangible safety problems by group and place.

Requires experts to perform.

It is a traditional tool in rational planning.
Size of the public space may limit a safety walk (e.g. a big park).

Results are dependent of who are participating in the survey, when (day or night, summer vs. winter) or the size of the group.

Difficult to engage vulnerable groups.

Participants represent particular interests.

Individuals that often participate are not fearful and know more about the area than other citizens.

Opens up for discussion of all sorts of subjects undermining the specific goal of the safety walk.

Views on women's needs and behaviour in Vingis Park tend to consolidate gender stereotypes (e.g. improper behaviour of girls in public places, drinking, and mothers with prams).

Gender dimension is limited to the analysis of men and women.

Difficulty to engage vulnerable groups (e.g. language barriers).

Costly.

Crime maps can be complemented by information gathered from safety walks, particularly when they show different areas of concern. Safety walks provide a holistic approach to safety as they potentially help the identification of safe/unsafe places in the park by different groups of users.

Although safety walks encourage communicative planning, engaging citizens and experts, and help empower groups to change public spaces, this technique also encounters a number of limitations. The size of the public space may limit a safety walk, for instance, in the case of a big park. Open invitations make it difficult to engage vulnerable groups (e.g., disabled individuals) or those who face limitations for integration in society (e.g., newly arrived immigrants. There is also a risk that those who do participate are not fearful and know more about the area than other citizens. Another issue is management of the safety walk. If not well guided, the safety walk opens up of all sorts of subjects for discussion, undermining the specific goal of the safety walk.

If more structured information about safety is required, safety surveys are more appropriate and have been proven to be a traditional but useful tool in planning. Using questionnaires, it is possible to show tangible safety problems by group and place, it does not require the participation of citizens all at once in time, and it may only require an expert to perform the survey. The presence of experts allows interaction with respondents, which can be useful when maps are used in the survey. In more structured safety surveys, data are highly dependent on the way the questions are framed. Perceptions of safety may vary over time (day and night, seasonally, before or after an event). Another problem is that fear of crime may hide many underlying anxieties that have little to do with the built environment that were asked in the survey. Compared with crime data and safety walks, surveys 
may be more costly. For the case of Vingis Park, these two methods were more informative to indicate safety conditions than the police data.

It has to be kept in mind that neither the answers gathered from the safety walk nor the safety survey were representative for the whole Vilnius population. Moreover, the conclusions drawn here are based on a limited sample from users of the park. Future studies should use a sample that can be representative for both permanent and temporary users. Daily and seasonal variations in temperature and illumination of the park might be important to consider when making new assessments of the park. Observational and experimental techniques from psychology could, for instance, be combined with the current techniques discussed in this study.

Suggestions of safe improvements in Vingis Park presented in this article are an illustration of actions that could be taken, but should not be considered as a solution for safety in parks elsewhere. In terms of recommendations for the particular case of Vingis Park, illumination should be improved, particularly where daylight may be limited in early mornings and late afternoons. Improved illumination provides also better visibility and conditions for surveillance during the dark winter days. Moreover, more comfortable sitting areas make the park more welcoming, contributing to the overall safety and comfort of park users. Clear placement of trash bins and signs encouraging users to put trash in the trash bins could reduce littering. Natural surveillance should be encouraged by allowing for legal performers or kiosks in certain areas of the park premises. They provide surveillance and often a welcoming atmosphere for the park. These workers may become natural guardians of their park and send a direct message that "someone cares" or that the park is "under control". Another solution is to invite park personnel and workers for safety training, which certainly would make them more prepared to respond to various types of emergencies. At the municipal level, there should be an officer responsible for safety throughout the park system.

The car traffic on the main roads crossing the park is an important safety problem. Speed limit signs should be installed at more spots around the park, together with signs showing ongoing children's activities. On the current paths, separate spaces for different users should be encouraged; for instance, two lanes separating pedestrians from bikers. In this case, safety interventions require co-operation between municipal transportation and safety authorities.

Parks may differ highly in their functions, some are city parks, and others offer a playground and lake, while others might be interstitial spaces between neighbourhoods. Future analysis of safety should consider these functions more integrally as part of the safety equation and plan for interventions. There is a need to adapt safety initiatives to the particular needs of communities and groups of individuals. Different groups have different needs and run different risks of being a victim of crime. Interventions should be tailored to the needs of particular groups. The question that has to guide our actions is: Do all groups genuinely feel safe at the park? Results seem to indicate that individual characteristics may interact with each other defining particular needs. For instance, being a woman and from an ethnic minority (this group was absent in both safety walk and safety survey) may provide new information about possible use of public places and fear, which was missing in this study.

There are groups that are often seen as a safety problem rather than as citizens who have the right to enjoy safety in public places. This may involve groups of young people but also drug and alcohol addicts. Park workers and police officers should work in partnership with the municipality to support those with addiction problems who spend considerable amounts of time in parks. Outreach teams should further encourage individuals to take advantage of the help and support on offer from the municipal social care, hospitals or non-governmental organizations. These actions require better coordination between municipal agencies and other institutions responsible for safety in public environments.

The most important impact of this method for local planning is the possibility of making the process more transparent for the actors, decision-makers, interest groups, and general public interested in safety issues in parks. The methodological procedures adopted here open opportunities for the implementation of dynamic and interactive forums around relevant questions for planning, where the general public should be invited to participate. Safety walks and safety surveys are examples of these forums. In the experience from Vingis Park, a step towards a more transparent planning process has already been taken. The arguments suggested above imply the development of new roles and responsibilities, not only for professionals who now manage police-recorded data and safety surveys and walks, but also for all those directly involved in local decision-making, including citizens. 


\section{Acknowledgements}

Authors would like to thank to Vilma Zidonyte and her colleagues at the Vilnius county Police Headquaters. Without her help the field work, safety walk and safety survey would not have been possible. They are also grateful to Vilnius municipality and Centre of equality advancement for help and collaboration. The project was partially funded through a scholarship from the Nordic Council of Ministers' Office in Estonia, in the programme Nordic Baltic Mobility Programme for Public Administration. Thanks also all those citizens who spent their time taking part in the safety walk and answering the safety survey.

\section{References}

Andrews, K. D. (2005). Mastering the post-socialist city: Impacts on planning the built environment. In F. E. Hamilton, K. D. Andrews, \& N. Pichler-Milanovic (Eds.), Tranformation of cities in central and Eastern Europe towards globalisation. United Nations: Tokyo.

Brennan, D., \& Zelinka, A. (2011). SafeScape: creating safer, more liveable communities. Alexander communications group.

Boverket, Tryggare och Mänskligare Göteborg and National council of crime prevenrion (BRÅ). (2010). Trygghetsvandring: en vägledning (Safety walks: a guide). Elanders Sverige, Stockholm.

Box, S., Hale, C., \& Andrews, G. (1988). Explaining fear of crime. British Journal of Criminology, 28(3), 340-356.

Bromley, R. D., \& Stacey, R. J. (2012). Feeling unsafe in urban areas: exploring older children's geographies of fear. Environment and Planning A, 44, 428-444. http://dx.doi.org/10.1068/a44224

Canter, D., \& Larkin, P. (1993). The environmental range of serial rapists. Journal of Environ-ment Psychology, 13(1), 63-69. http://dx.doi.org/10.1016/S0272-4944(05)80215-4

Ceccato, V., \& Snickars, F. (2000). Adapting GIS technology to the needs of local planning. Environment and Planning B, 27, 923-938. http://dx.doi.org/10.1068/b26103

Ceccato, V. (2009). Crime in a city in transition: the case of Tallinn, Estonia. Urban Studies, 46(8), 1593-1610. http://dx.doi.org/10.1177/0042098009105501

Ceccato, V., \& Oberwittler, D. (2008). Comparing spatial patterns of robbery: evidence from a Western and a Eastern European city. Cities, 25, 185-196. http://dx.doi.org/10.1016/j.cities.2008.04.002

Ceccato, V., \& Lukyte, N. (2011) Safety and sustainability in a city in transition: the case of Vilnius, Lithuania. Cities, 28, 83-94. http://dx.doi.org/10.1016/j.cities.2010.10.001

Chiesura, A. (2004). The role of urban parks for the sustainable city. Landscape and Urban Planning, 68, 129-138. http://dx.doi.org/10.1016/j.landurbplan.2003.08.003

Damyanovic, D. (2007). Gender Mainstreaming as a strategy for sustainable urban planning procedures. Vienna: University of Natural Resources and Applied Life Sciences (BOKU), Institute of Landscape.

DeJoy, D. M. (1992). An examination of gender differences in traffic accident risk perception. Accident Analysis and Prevention, 24(3), 237-246. http://dx.doi.org/10.1016/0001-4575(92)90003-2

Dymen, C., \& Ceccato, V. (2012). An international perspective of the gender dimension in planning for urban safety. In A. Ceccato (Ed.), The urban fabric of crime and fear. Springer (pp. 311-341).

Fobker, S., \& Grotz, R. (2006). Everyday Mobility of Elderly People in Different Urban Settings: The Example of the City of Bonn, Germany. Urban Studies, 43, 99. http://dx.doi.org/10.1080/00420980500409292

Geoghegan, J. (2002). The value of open spaces in residential land use. Land Use Policy, 19, 91-98. http://dx.doi.org/10.1016/S0264-8377(01)00040-0

Groff, E., \& McCord, E. S. (2011). The role of neighbourhood parks as crime generators. Security journal, 1-24.

Hansmann, R., Hug, S. M., \& Seeland, K. (2007) Restoration and stress relief through physical activities in forests and parks. Urban Forestry \& Urban Greening, 6, 213-225. http://dx.doi.org/10.1016/j.ufug.2007.08.004

Herzog, T. R., \& Kirk, K. M. (2005). Pathway curvature and border visibility as predictors of preference and danger in forest settings. Environment and Behaviour, 37, 620-639. http://dx.doi.org/10.1177/0013916505275306

Hilborn, J. (2009). Dealing with crime and disorder in urban parks. Problem-Oriented Guides for Police 
Response Guides Series (Vol. 9).

Hirt, S. (2012). Iron curtains: Gates, suburbs and privatization of space in the Post-socialist City. Wiley Blackwell, Oxford. http://dx.doi.org/10.1002/9781118295922

Hoogensen, G., \& Stuvøy, K. (2006). Gender, Resistance and Human Security. Security Dialogue, 37, 207-228. http://dx.doi.org/10.1177/0967010606066436

Jacobs, J. (1961). The Death and Life of Great American Cities. Vintage Books. New York, USA.

Jim, C. Y., \& Chen, W. Y. (2010) External effects of neighbourhood parks and landscape elements on high-rise residential value. Land Use Policy, 27, 662-670. http://dx.doi.org/10.1016/j.landusepol.2009.08.027

Juskevicius, P. (2006). Vilniaus miesto socialine $\mathrm{s}$ erdve $\mathrm{s}$ ir deviacijos (Social spaces and deviations of Vilnius). Urbanistika ir architektura (Town Planning and Architecture), 2, 69-77.

Knutsson, J. (1997). Restoring public order in a city park (pp. 133-151). National Council for Crime Prevention, $\begin{array}{lllll}\text { Sweden. } & \text { Retrieved } & \text { October } & 30, & \text { 2012, }\end{array}$ http://www.popcenter.org/library/CrimePrevention/Volume_07/05_knuttson.pdf

Koskela, H. (1999). Fear, control and space: geographies of gender, fear of violence, and video surveillance (PhD thesis). Helsinki: University of Helsinki.

Kunieda, M., \& Gauthier, A. (2007). Gender and urban transport: fashionable and affordable. Sustainable transport: a sourcebook for police makers in developing cities. Eschborn: GTZ.

Kou, F. E., \& Sullivan, W. E. (2001). Environment and Crime in the Inner City: Does Vegetation Reduce Crime? Environment and Behaviour, 33, 343-367.

Larsson, A., \& Jalakas, A. (2008). Jämställdhet nästa! Samhällsplanering ur ett genusperspektiv (Equality next! Urban planning from a gender perspective). Stockholm: SNS förlag.

Loukaitou-Sideris, A., Liggett, R., \& Iseki, H. (2002). The Geography of transit crime: documentation and evaluation of crime incidence on and around Green Line stations in Los Angeles. Journal of Planning Education and Research, 22(2), 135-151. http://dx.doi.org/10.1177/0739456X02238443

Loukaitou-Sideris, A., Bornstein, A., Fink, C., Samuels, L., \& Gerami, S. (2009). How to ease women's fear of transportation environments: Case studies and best practices. MTI REPORT 09-01. Retrieved February 19, 2011 from http://transweb.sjsu.edu/mtiportal/research/publications/documents/Sideris.pdf

Michael, S., Hull, R., \& Zahm, D. (2001) Environmental factors influencing auto burglary-a case study. Environment and Behaviour, 33, 368-388. http://dx.doi.org/10.1177/00139160121973034

Mollenkopf, H., \& Flaschenträger, P. (2001). Erhaltung von Mobilität im Alter (Preservation of mobility in old age). Stuttgart: W. Kohlhammer.

Newman, O. (1972). Defensible Space: Crime Prevention through Urban Design. Macmillan, New York, USA.

Nicholls, S., \& Crompton, J., (2005). The impact of greenways on property values: evidence from Austin, Texas. Journal of Leisure Research, 37, 321-341.

Pain, R. H. (1991). Space, sexual violence and social control: integrating geographical and femi-nist analyses of women's fear of crime. Progress in Human Geography, 15(4), 415-431. http://dx.doi.org/10.1177/030913259101500403

Pain, R. H. (1997). Social geographies of women's fear of crime. Transactions of the Institute of British Geographers, 22(2), 231-244.

Pyle, G. F. (1974). The spatial dynamics of crime (Research Paper No. 159). Chicago: Depart-ment of Geography, University of Chicago.

Peiser, R., \& Schwann, G. (1993). The private value of public open space within subdivisions. Journal of Architectural and Planning Research, 10, 91-104.

Sandercock, L. (2005). Difference, fear and habitus, a political economy of urban fear. In J. Hillier, \& E. Rooksby (Eds.), Habitus: a sense of place (pp. 219-233). Aldershot: Ashgate.

Sherman, L. W., Gartin, P. R., \& Buerger, M. E. (1989). Hot spots of predatory crime: routine activities and the criminology of place. Criminology, 27(1), 27-55. http://dx.doi.org/10.1111/j.1745-9125.1989.tb00862.x

Skogan, W. G., \& Maxfield, M. G. (1981). Coping with Crime. Newbury Park, CA: Sage. 
Thompson, C. W., Roe, J., Aspinall, P., Mitchell, R., Clowd, A., \& Miller, D. (2012). More green space is linked to less stress in deprived communities: Evidence from salivary cortisol patterns. Landscape and Urban Planning, 105, 221-229. http://dx.doi.org/10.1016/j.landurbplan.2011.12.015

Tosics, I. (2005). City development in Central and Eastern Europe since 1990: The impacts of internal forces. In F. E. Hamilton, K. D. Andrews, \& N. Pichler-Milanovic (Eds.), Tranformation of cities in central and Eastern Europe towards globalisation. United Nations: Tokyo.

Tsenkova, S. (2006). Beyond transitions: Understanding urban change in post-socialist cities. In S. Tsenkova, \& Z. Nedovic-Budic (Eds.), The urban mosaic of pos-socialist Europe, space, institutions and policy. Physical Verlag: Heidelberg, New York. http://dx.doi.org/10.1007/3-7908-1727-9_2

Tyrvainen, L. (1997). The amenity value of the urban forest: an application of the hedonic pricing method. Landscape and Urban Planning, 37, 211-222. http://dx.doi.org/10.1016/S0169-2046(97)80005-9

Tyrväinen, L., \& Mäkinen, K. (2004). Tools for Mapping Social Values and Meanings of Urban Woodlands and Other Open Space (pp. 1-6). Department of Forest Ecology, University of Helsinki.

United Nations Economic Commission for Europe (UNECE). (1995). Trends in Europe and North America. The Statistical Yearbook of the Economic Commission for Europe. New York and Geneva: UNECE.

VCCAV (Victorian Community Council against Violence). (1995). Safety audits: Past experience and future strategies. Unpublished notes from a March 1995 Forum, Melbourne: VCCAV.

WACAV (Women's Action Centre Against Violence Ottawa-Carleton). (1995). Safety Audit Tools and Housing: The State of the Art and Implications for CMHC. Ottawa, Canada: Canada Mortgage and Housing Association.

Vilnius City Police Headquarters. (2007). Saugi kaiminyste (Safe neighbourhood). Retrieved August 23, 2007, from http://www.nplc.lt/sena/lit/lit60.pdf

Whitzman, C. (2007). Stuck at the front door: gender, fear of crime and the challenge of creating safer space. Environment and Planning A, 39(11), 2715-2732. http://dx.doi.org/10.1068/a38449

Whitzman, C., Shaw, M., Andrew, C., \& Travers, K. (2009). The effectiveness of women's safety audits. Security Journal, 22(3), 205-218. http://dx.doi.org/10.1057/sj.2009.1

\section{Appendix}

\section{Safety Survey}

1. How often do you come to Vingis in the spring/summer?

- 3 times or more per week

- less than 3 times per week

- more than 3 times per Month

- $\quad$ less than 3 times per month

- $\quad$ first time I' $m$ visiting Vingis Park this year

2. How often do you come to Vingis in the cold months of the year?

- more than 3 times per week

- less than 3 times per week

- more than 3 times per month

- $\quad$ less than 3 times per month

- I don't visit Vingis Park during the cold season

3. Why come to the park?

- recreation

- meeting friends and/or relatives

- leisure

- $\quad$ sports

- just passing by in the park

- I'm working in Vingis park

- other reasons (walking with child, walking with the dog)

4. Is it easy to go around in the park? (find things/orientate) 
- it is difficult for me to orientate

- it is a little bit difficult for me to orientate

- it is not difficult for me to orientate

- don't know

5. Do you experience unpleasant events that disturb you at Vingis park? (either to you or others)

- Yes, quite often

- Yes, sometimes

- Rarely

- Not at all

- don't know

- What?

6. It happens while I'm in Vingis that I hear sounds/n that I wouldn't like to hear

- yes quite often

- yes sometimes

- very rarely

- not at all

- don't know

7. I see private guards and/or police around in Vingis Park

- yes quite often

- yes sometimes

- very rarely

- not at all

- don't know

8. I feel safe to walk around in Vingis park

- yes absolutely

- yes to some extent

- I don't feel safe or unsafe

- I don't feel so safe

- I don't feel safe at all

9. If yes, where do you feel unsafe?

- (a map of the park is given to the person who is invited to indicate places that are felt as unsafe in Vingis)

10. Do you feel safe in your neighbourhood?

- yes absolutely

- yes to some extent

- I don't feel safe or unsafe

- I don't feel so safe

- I don't feel safe at all

11. Do you feel safe in Vilnius?

- yes absolutely

- yes to some extent

- I don't feel safe or unsafe

- I don't feel so safe

- I don't feel safe at all

12. If you think about safety in Vingis, what could be improved?

13. Personal characteristics of the interviewee (e.g., gender, age)

\section{Copyrights}

Copyright for this article is retained by the author(s), with first publication rights granted to the journal.

This is an open-access article distributed under the terms and conditions of the Creative Commons Attribution license (http://creativecommons.org/licenses/by/3.0/). 